\title{
Knowledge and practice of clinical ethics among healthcare providers in a government hospital, Chennai
}

\author{
THILAKAVATHI SUBRAMANIAN', A K MATHAI ${ }^{2}$, NANDINI KUMAR ${ }^{3}$
}

'Deputy Director, Scientist E, National Institute of Epidemiology, Indian Council of Medical Research, Second Main Rd, Ayapakkam Chennai 600077 INDIA ${ }^{2}$ Research Assistant, National Institute of Epidemiology, ICMR, Second Main Rd, Ayapakkam, Chennai 600077 INDIA ${ }^{3}$ Former Deputy Director General (Senior Grade), Scientist F, Indian Council of Medical Research, New Delhi 110027 INDIA Corresponding author:Thilakavathi Subramanian e-mail: thilakavathi_s@rediffmail.com

\begin{abstract}
The growing public concern about the ethical conduct of healthcare professionals highlights the need to incorporate clinical ethics in medical education. This study examined the knowledge and practice of clinical ethics among healthcare providers in a government hospital in Chennai. A sample of 51 treating physicians and 58 other non-physician service providers from the hospital answered a self-administered, semi-structured questionnaire on their knowledge of and adherence to ethical principles, and the problems they faced related to healthcare ethics. More than 30\% did not give a definition of healthcare ethics, and $40 \%$ did not name a single ethical principle. $51 \%$ stated that they witnessed ethical problems in their settings and named patient dissatisfaction, gender bias by provider, and not maintaining confidentiality. The responses of healthcare providers to various ethical scenarios are reported.
\end{abstract}

\section{Background}

The increasing number of complaints against healthcare professionals may be due to increased public awareness of unethical practices. After completing their studies, healthcare professionals are expected to know ethical principles and apply them in their clinical practice (1). However, medical training in India provides little guidance for healthcare professionals to resolve the ethical dilemmas they encounter. Reports have stressed the need to incorporate ethical and legal issues in healthcare into medical curricula (2-4).

Ethics is a generic term referring to the moral code of conduct in a civil society and the rules, customs and beliefs of that society. It is generally agreed that 'morality' is all about what is right and wrong based on socially approved norms of human conduct. From childhood, we learn moral rules along with other social rules. Later in life, we are able to distinguish between general social rules held by all members of society, and specific social rules - or ethical guidelines -- binding the members of special groups such as a profession (5).

Healthcare ethics deals with how providers apply a moral code of conduct to patients in a healthcare setting, taking into account the patients' self respect, individuality, safety and welfare. Clinical ethics refers to the ethics of activity in the clinical setting, which if practised, will lead to more ethical care (6). For clinical personnel to practise clinical ethics, their clinical expertise and subject training need to be honed by appropriate clinical ethics training (7).
This study aimed to learn the knowledge and practice of clinical ethics among healthcare providers in an Indian government hospital in Chennai. On an average, more than 2,000 outpatients attend this hospital daily, and there are more than 2,000 inpatients in the hospital on any given day (as per the 2008 census from the hospital). Since the hospital largely caters to the lower socio-economic segment of the population, it was considered important to study healthcare providers here, for their knowledge and practice of clinical ethics in the delivery of services.

\section{Methods}

This was a descriptive, cross-sectional study. Healthcare providers in the government general hospital -- one group consisting of treating physicians and the other of all other service providers in the same setting who would come in contact with patients -- with an experience of two years or more, formed the study population. A list of healthcare providers of all the departments fulfilling the above inclusion criteria was obtained and arranged in alphabetical order forming the sampling frame. Based on this, a list was prepared using population proportionate to size sampling from each required category of staff. From this list, a random sample of 121 was selected, using random number table and asked to respond to the questionnaire. 11 refused to respond; seven said they had "no time to respond" and four said they were "not interested". Thus, a total of 109 providers from various departments responded to the questionnaire. There were 51 physicians and 58 non-physician providers -- nurses, pharmacists, physiotherapists, counsellors, social workers, clerks and technicians.

\section{Data collection}

The director of medical education and the dean of the hospital were approached for permission to conduct this study. After obtaining permission, the investigator obtained permission from the department heads and then approached the sampled staff to participate after informing them about the purpose of the study and the procedure. Respondents who gave their written informed consent were given a semi-structured questionnaire and asked to complete and return it. The first part of the questionnaire asked questions on the respondents' knowledge of ethics, clinical ethics/healthcare ethics and ethical problems they witnessed in hospital settings. In the second part, to determine the participants' understanding of ethical concepts such as autonomy, confidentiality and 
informed consent, a 5 point Likert scale was developed, where the possible responses were strongly agree, agree, no opinion, disagree, or strongly disagree. Physicians were given an additional set of statements related to their own medical practices, and questions on their recollection of the Hippocratic Oath.

\section{Data analysis}

Descriptive analysis was carried out using SPSS package (version 14.0). The responses of the five point Likert scale were grouped into two, one with responses of Strongly agree and Agree and the other group having the remaining three responses namely, No comments, Disagree and Strongly disagree. These two groups of responses to each question were compared and tested using Pearson's Chi-square test.

\section{Human subject protection}

The proposal was reviewed and approved by the institutional ethics committee of the National Institute of Epidemiology.

\section{Results}

109 personnel from various departments answered the questionnaire. Their basic characteristics are given in Table 1.

\section{Knowledge of "ethics" and "healthcare ethics"}

Table 2 describes respondents' definition of ethics and healthcare ethics.

$23 / 51(46 \%)$ of physicians and $10 / 58(18 \%)$ of non-physicians when asked to define ethics, reported: "Ethics means moral principles or moral rules to be followed." 10/51 (16\%) of physicians and 13/28 (23\%) of non-physicians informed ethics as a "code of conduct". 12/109 (11\%) of all respondents told 'others' and 23/109 (21\%) of all respondents did not give any response.

When asked to define "healthcare ethics", 12/51 (24\%) of physicians and $7 / 58$ (10\%) of non-physicians gave the definition: "Ethics to be followed by healthcare professionals". $7 / 51$ (14\%) of physicians and 4/58 (6\%_ of non-physicians informed:"Healthcare ethics means moral values to be followed for the welfare of the patients."34/109 (31\%) of all respondents gave no response.

When asked to name all the people whose work requires the application of healthcare ethics (data not shown), respondents mentioned doctors, nurses, social workers and physiotherapists. 92\% of respondents identified doctors and 93\% mentioned nurses as the persons to apply healthcare ethics or clinical ethics while on duty at hospitals. 53\% mentioned social workers and $49 \%$ mentioned physiotherapists.

\section{Ethical problems}

Tables 3 and 3a give respondents' reports on ethical problems they witnessed in their day-to-day work at the hospital. 22/51 $(43 \%)$ of the physicians and $33 / 58(57 \%)$ of the non-physicians stated that they witnessed situations of ethical concern.
When those who reported witnessing such situations were asked to name the single most common unethical practice encountered, 12/109 (22\%) of all respondents mentioned patient dissatisfaction with treatment and 9/109 (16\%) of all respondents mentioned providers' gender bias in the treatment of patients.

\section{Basic ethical principles in dealing with patients}

Table 4 gives respondents' comments when asked to identify the single basic principle of ethics from a list of options. "Treating patients properly and kindly" was mentioned as the basic principle by $8 / 51$ (16\%) of physicians and $10 / 58$ (17\%) of non-physicians. Taking the patient's consent before beginning any investigation or treatment was mentioned by $6 / 51$ (12\%) of the physicians and $12 / 58$ (21\%) of the non-physicians as another basic principle of ethics. In all, 43/109 (40\%) of the respondents did not answer this question.

Respondents were asked to choose the most important skill for healthcare professionals in dealing with patients (data not given). $31 \%$ of both groups combined chose "listening" $16 \%$ chose "showing concern" and 15\% chose "explaining all procedures".

\section{Healthcare providers' practice of ethics}

Table 5 gives the responses of physicians and non-physicians on various aspects of the practice of clinical or healthcare ethics. Respondents were asked whether they strongly agreed, agreed, had no comments, disagreed or strongly disagreed with given situation statements. There were significant differences $(p<0.05)$ between the reported behaviour of physicians and non-physicians on whether they considered patients' wishes before taking major decisions on their care; whether their mood affected their care of patients; whether they refused to treat violent patients, whether they did what is best for the patient irrespective of the patient's opinion, and whether they agreed with patients who requested their help in dying.

There were no significant differences in the opinions of physicians and non-physicians regarding other issues such as discrimination, informing patients about the investigations, treatment procedures and the risks involved, taking consent from patients or relatives, maintaining confidentiality and the need to consult the seniors for the sake of patients.

\section{Physicians' practices and knowledge}

Table 6 gives physicians' reported practices in various situations related to ethical practice. The majority obtained patients' permission before examining them, informed close relatives about the patient's condition, and would not treat children without the parent's consent. 43/51 stated that doctors could not refuse to perform abortion if the law permitted it. 23/51 stated that if a patient refused a particular treatment for religious reasons, they would refer them to another doctor. $25 / 51$ stated that they did not have time to spend listening to their patients. Just seven out of 51 would treat patients even when unable, rather than refer them to a more suitable doctor 


\begin{tabular}{|c|c|c|c|c|c|c|c|}
\hline \multirow{2}{*}{$\begin{array}{l}\text { Table } \\
\text { Charact- } \\
\text { eristics }\end{array}$} & \multirow[t]{2}{*}{ Categories } & \multicolumn{2}{|c|}{$\begin{array}{l}\text { Physicians } \\
\text { (n=51- } \\
47 \%)\end{array}$} & \multicolumn{2}{|c|}{$\begin{array}{l}\text { Non- } \\
\text { physicians } \\
(\mathrm{n}=58-53)\end{array}$} & \multicolumn{2}{|c|}{$\begin{array}{l}\text { Total } \\
(n=109)\end{array}$} \\
\hline & & No. & $\%$ & No. & $\%$ & No. & $\%$ \\
\hline \multirow{2}{*}{ Gender } & Male & 29 & 57 & 17 & 29 & 46 & 42 \\
\hline & Female & 22 & 43 & 41 & 71 & 63 & 58 \\
\hline \multirow{4}{*}{$\begin{array}{l}\text { Age (in } \\
\text { years) }\end{array}$} & $<25$ & 4 & 8 & 3 & 5 & 7 & 6 \\
\hline & $25-34$ & 33 & 65 & 5 & 8 & 38 & 35 \\
\hline & $35-44$ & 11 & 22 & 30 & 52 & 41 & 38 \\
\hline & $\geq 45$ & 3 & 6 & 20 & 35 & 23 & 21 \\
\hline \multirow[t]{4}{*}{ Education } & MBBS/degree or diploma in nursing & 23 & 45 & 21 & 36 & 44 & 40 \\
\hline & MD/diploma in pharmacy & 27 & 53 & 16 & 28 & 43 & 39 \\
\hline & postgraduate diploma/physiotherapy & 1 & 2 & 13 & 22 & 14 & 13 \\
\hline & Others & - & - & 8 & 14 & 8 & 7 \\
\hline \multirow[t]{10}{*}{ Designation } & Physicians & & & & & & \\
\hline & Postgraduate assistant & 33 & 67 & & & 33 & 66 \\
\hline & Assistant professor & 15 & 29 & & & 15 & 29 \\
\hline & Tutor & 2 & 4 & & & 2 & 4 \\
\hline & No answer & 1 & 2 & & & 1 & 2 \\
\hline & Non-physicians & & & & & & \\
\hline & Nurses & & & 23 & 40 & 23 & 40 \\
\hline & Pharmacists & & & 16 & 28 & 16 & 28 \\
\hline & Physiotherapist & & & 14 & 24 & 14 & 24 \\
\hline & $\begin{array}{l}\text { Others (social workers, registry clerks, } \\
\text { counsellors and laboratory technicians) }\end{array}$ & & & 5 & 8 & 5 & 8 \\
\hline
\end{tabular}

Note: Percentages rounded off

Physicians were asked how much they remembered of the Hippocratic Oath (data not given). 10/51 said they remembered nothing; $11 \%$ did not respond. When asked to name the principles of the oath, physicians named empathy for patients, taking patients' consent before treatment, serving the poor and needy, and maintaining confidentiality.25/51 did not respond.

\section{Discussion}

The findings of this study suggest that both physicians and non-physicians need more knowledge of healthcare ethics. The fact that many respondents had "no answer" to some questions may indicate their lack of awareness or knowledge in that area, their inability to decide or commit a specific response, or their disinterest.

Basic training in clinical ethics should incorporate in its framework the four approaches of applied ethics, casuistry, principlism and specific techniques for resolving conflicts or disagreements to 'doing' clinical ethics (6). Besides providing core competencies in assessment, processing and interpersonal skills, higher education develops clinical ethics skills, knowledge and character traits (7).

Traditionally, healthcare personnel receive limited formal training in ethics, though their day-to-day work involves direct or indirect need for knowledge in this area (8). The view has been strongly expressed that teaching and training of ethics should be a continuous process in medical and nursing education (9). It is also suggested that medical and nursing students could be taught together in interdisciplinary settings in order to improve ethical practice in healthcare (10).

\section{Limitations}

Providers' practices were self-reported and their responses may have been tailored according to what they believed were appropriate. Though the sample is representative of the study population, the number is too small to generalise the findings to all hospital healthcare providers.

\section{Conclusion}

The study found that physicians and non-physicians reported encountering a number of ethical issues when dealing with patients. Most healthcare professionals are not aware of the importance of healthcare ethics. This emphasises the need to provide knowledge of ethics in the curriculum at the undergraduate level, provide healthcare personnel training in clinical ethics in healthcare settings. In the course of their service, they should receive periodic continuing education to emphasise basic principles of ethics like autonomy, privacy, confidentiality, need of taking well informed consent, and issues related to patients with diseases of a sensitive nature. This would enable providers to resolve ethical issues that arise frequently in clinical settings.

\section{Acknowledgements}

The authors thank the government officials who permitted us to conduct this study in the hospital and thank the staff who spared their time to answer our questionnaire.

\section{References}

1. Howitt M. Medical ethics.Barbados Association of Medical Practitioners Bulletin.2002:152-5.

2. Roff S, Preece P. Helping medical students to find their moral compasses: ethics teaching for second and third year undergraduates. J Med Ethics.2004 Oct;30(5);487-9.

3. Eckles RE, Meslin EM, Gaffney M, Helft PR. Medical ethics education: where are we? Where should we be going? A review. Acad Med. 2005 Dec;80(2):1143-52.

4. Mattick K, Bligh J.Teaching and assessing medical ethics: where are we now? J Med Ethics. 2006 Mar; 32(3):181-5.

5. Reading material for on-line post graduate diploma course in bio-ethics under ICMR and IGNOU joint initiative, 2011.

6. Agich GJ. What kind of doing is clinical ethics? Theor Med Bioeth. 2005; 26(1):7-24.

7. Chidwick P, Faith K, Godkin D, Hardingham L. Clinical education of ethicists: the role of a clinical ethics fellowship, BMCMed Ethics. $2004 \mathrm{Nov}$ 8;5:E6.

8. Aarons DE. Issues in bioethics. Teaching bioethics to health professionals. West Indian Med J. 2002 Jun;51(2):59 - 63.

9. Aarons DE. Issues in bioethics. Teaching research ethics. West Indian Med J. 2003 Jun; 52(2):145-50.

10. Hanson S.Teaching health care ethics: why we should teach nursing and medical students together. Nurs Ethics. 2005 Mar;12(2):167-76. 


\begin{tabular}{|c|c|c|c|c|c|c|c|}
\hline Characteristics & Definition & \multicolumn{2}{|c|}{$\begin{array}{l}\text { Physicians } \\
(n=51)\end{array}$} & \multicolumn{2}{|c|}{$\begin{array}{c}\text { Non- } \\
\text { physicians } \\
(\mathrm{n}=58)\end{array}$} & \multicolumn{2}{|c|}{$\begin{array}{l}\text { Total 1. } \\
(n=109)\end{array}$} \\
\hline \multirow{7}{*}{$\begin{array}{l}\text { Definition of } \\
\text { ethics }\end{array}$} & & No. & $\%$ & No. & $\%$ & No. & $\%$ \\
\hline & Moral principles/rules to be followed & 23 & 46 & 10 & 18 & 33 & 30 \\
\hline & Code of conduct & 10 & 16 & 13 & 23 & 23 & 21 \\
\hline & Not affecting others' freedom & 5 & 10 & 3 & 5 & 8 & 7 \\
\hline & Service to patients/to be sympathetic & - & - & 10 & 17 & 10 & 9 \\
\hline & $\begin{array}{l}\text { 'Other'(responses given were: "confidentiality", "legally correct", "socially acceptable", } \\
\text { "correct behaviour", "physician credibility") }\end{array}$ & 4 & 10 & 8 & 14 & 12 & 11 \\
\hline & No answer & 9 & 18 & 14 & 24 & 23 & 21 \\
\hline \multirow{8}{*}{$\begin{array}{l}\text { Definition of } \\
\text { healthcare } \\
\text { ethics }\end{array}$} & Ethics to be followed by healthcare professionals & 12 & 24 & 7 & 10 & 19 & 17 \\
\hline & Managing healthcare problems & 9 & 18 & 2 & 3 & 11 & 10 \\
\hline & Moral values to be followed for the welfare of patients & 7 & 14 & 4 & 6 & 11 & 10 \\
\hline & Treating patients with kindness & 3 & 6 & 8 & 14 & 11 & 10 \\
\hline & Maintaining confidentiality & 1 & 2 & 5 & 9 & 6 & 6 \\
\hline & Awareness for good health & - & - & 5 & 9 & 5 & 5 \\
\hline & $\begin{array}{l}\text { 'Other' (responses were: "good relationship between patients and staff", "as per } \\
\text { Hippocratic Oath", "neat and tidy", "wealth and health") }\end{array}$ & 2 & 3 & 10 & 18 & 12 & 11 \\
\hline & No answer & 17 & 33 & 17 & 29 & 34 & 31 \\
\hline
\end{tabular}

Note: Percentages rounded off

Table 3. Respondents' reporting of unethical practices : Whether respondents witnessed ethical problems

\begin{tabular}{|l|c|c|c|c|c|c|}
\hline Witnessing ethical problems & Physicians $(\mathbf{n = 5 1 )}$ & $\mathbf{\%}$ & Non-physicians $(\mathbf{n}=\mathbf{5 8})$ & $\mathbf{\%}$ & Total $(\mathbf{n = 1 0 9 )}$ & $\mathbf{\%}$ \\
\hline & No. & $\%$ & No. & $\%$ & No. & $\%$ \\
\hline Yes & 22 & 43 & 33 & 57 & 55 \\
\hline No & 29 & 57 & 25 & 43 & 54 & 49 \\
\hline
\end{tabular}

Note: Percentages rounded off

\begin{tabular}{|c|c|c|c|c|c|c|}
\hline \multirow[t]{2}{*}{ Types of ethical problems mentioned by respondents (the most common one) } & \multicolumn{2}{|c|}{$\begin{array}{l}\text { Physicians } \\
(\mathbf{n}=22)\end{array}$} & \multicolumn{2}{|c|}{$\begin{array}{c}\text { Non-physicians } \\
(n=33)\end{array}$} & \multicolumn{2}{|c|}{$\begin{array}{l}\text { Total } \\
(n=55)\end{array}$} \\
\hline & No. & $\%$ & No. & $\%$ & No. & $\%$ \\
\hline Patient dissatisfaction with treatment & 4 & 18 & 8 & 24 & 12 & 22 \\
\hline Providers' gender bias when treating patients & 4 & 18 & 5 & 15 & 9 & 16 \\
\hline Delays in the clinic & 2 & 9 & 3 & 9 & 5 & 9 \\
\hline Not listening to patients & 2 & 9 & - & -- & 2 & 4 \\
\hline Not maintaining confidentiality & 2 & 9 & 1 & 3 & 3 & 5 \\
\hline Not treating patients for other complaints (referred to the respective departments) & - & - & 2 & 6 & 2 & 4 \\
\hline Absence of medicines & 1 & 5 & - & - & 1 & 2 \\
\hline Wrong answer (having no infrastructure, canteen problems, etc.) & 2 & 9 & 7 & 21 & 9 & 16 \\
\hline No answer & 5 & 23 & 7 & 21 & 12 & 22 \\
\hline
\end{tabular}

Note: Percentages rounded off

\begin{tabular}{|c|c|c|c|c|c|c|c|c|}
\hline S.No. & Characteristic & \multirow[t]{2}{*}{ Categories } & \multicolumn{2}{|c|}{$\begin{array}{c}\text { Physicians } \\
(n=51)\end{array}$} & \multicolumn{2}{|c|}{$\begin{array}{c}\text { Non-physicians } \\
(n-58)\end{array}$} & \multicolumn{2}{|c|}{$\begin{array}{c}\text { Total } \\
(n=109)\end{array}$} \\
\hline \multirow[t]{9}{*}{1.} & \multirow{9}{*}{$\begin{array}{l}\text { Basic ethical } \\
\text { principles }\end{array}$} & & No. & $\%$ & No. & $\%$ & No. & $\%$ \\
\hline & & Respecting patients' views & 4 & 8 & 1 & 2 & 5 & 5 \\
\hline & & Treating the patients kindly/properly & 8 & 16 & 10 & 17 & 18 & 16 \\
\hline & & Investigations and treatment after obtaining consent & 6 & 12 & 12 & 21 & 18 & 16 \\
\hline & & Not to harm in any way & 4 & 8 & 1 & 2 & 5 & 5 \\
\hline & & \begin{tabular}{|l|} 
Truthfulness/sincerity/empathy/with better \\
understanding
\end{tabular} & 5 & 10 & 9 & 14 & 14 & 12 \\
\hline & & Treating to patients' satisfaction & - & - & 3 & 5 & 3 & 3 \\
\hline & & Others & 2 & 4 & 1 & 2 & 3 & 3 \\
\hline & & No answer & 22 & 43 & 21 & 38 & 43 & 40 \\
\hline
\end{tabular}

Note: Percentages rounded off 


\begin{tabular}{|c|c|c|c|c|c|c|}
\hline \multirow[t]{3}{*}{ S.No } & \multirow[t]{3}{*}{$\begin{array}{l}\text { Statements } \\
\text { (In a situation like this.....) }\end{array}$} & \multicolumn{4}{|c|}{ Agree } & \multirow[t]{3}{*}{ P value } \\
\hline & & \multicolumn{2}{|c|}{ Physicians $(\mathrm{n}=51)$} & \multicolumn{2}{|c|}{ Non-physicians $(n=58)$} & \\
\hline & & No. & $\%$ & No. & $\%$ & \\
\hline 1. & $\begin{array}{l}\text { I usually consider patients' wishes and views before } \\
\text { taking any major decision for their care. }\end{array}$ & 44 & 85 & 53 & 91 & $0.002^{*}$ \\
\hline 2. & $\begin{array}{l}\text { I will "dispose of" patients quickly, whenever I am in a } \\
\text { bad mood for personal reasons. }\end{array}$ & 34 & 67 & 39 & 68 & $0.021^{*}$ \\
\hline 3. & $\begin{array}{l}\text { I always maintain a distance with leprosy, TB or AIDS } \\
\text { patients as I am afraid of getting infected. } \\
\end{array}$ & 38 & 75 & 41 & 71 & 0.517 \\
\hline 4. & $\begin{array}{l}\text { I always explain to patients the risk (physical/mental/ } \\
\text { social) involved in any investigational or treatment } \\
\text { procedures. }\end{array}$ & 38 & 74 & 53 & 91 & 0.132 \\
\hline 5. & I refuse to treat or deal with a violent patient. & 28 & 55 & 49 & 85 & $0.001^{*}$ \\
\hline 6. & $\begin{array}{l}\text { I do not take consent from patients or their relatives for } \\
\text { any minor or major procedures or in collecting sensitive/ } \\
\text { personal data. }\end{array}$ & 45 & 88 & 47 & 81 & 0.158 \\
\hline 7. & I do the best for patients, irrespective of their opinion. & 41 & 81 & 43 & 74 & $0.033^{*}$ \\
\hline 8. & $\begin{array}{l}\text { If a patient wishes to die, I assure or help him/her in } \\
\text { doing so. }\end{array}$ & 28 & 54 & 44 & 76 & $0.000^{*}$ \\
\hline 9. & $\begin{array}{l}\text { Whenever I deal with AIDS or STD patients I maintain } \\
\text { confidentiality. }\end{array}$ & 44 & 86 & 56 & 97 & 0.182 \\
\hline 10. & $\begin{array}{l}\text { Whenever there is a need to consult my seniors for } \\
\text { patient care I always take their views. }\end{array}$ & 44 & 86 & 54 & 93 & 0.674 \\
\hline
\end{tabular}

$\mathrm{P}<0.05^{*}=$ significant

Table 6. Physicians personnel's responses for situations requiring basic ethical principles

\begin{tabular}{|l|l|c|}
\hline S.No & $\begin{array}{l}\text { Statements } \\
\text { (In a situation like this.....) }\end{array}$ & \multicolumn{2}{c|}{ Response (n=51) } \\
\cline { 2 - 3 } & Yes & No \\
\hline 1. & $\begin{array}{l}\text { I believe that close relatives should always be told about the patient's condition and inform my patients' } \\
\text { relatives accordingly. }\end{array}$ & 39 \\
\hline 2. & If a patient refuses treatment due to his/her religious beliefs, I instruct him/her to find another doctor & 23 \\
\hline 3. & If the law allows abortion, I or any other doctor should not refuse to conduct one. & 28 \\
\hline 4. & Inever treat children without the consent of their parents. & 43 \\
\hline 5. & I always obtain permission from patients before doing any physical or internal examination. & 39 \\
\hline 6. & I do not have enough time to listen to the stories of my patients. & 46 \\
\hline 7. & $\begin{array}{l}\text { Even if I am unable to treat a patient, I will somehow manage and try to do my best for the patient, but I will } \\
\text { not refer him/her to a suitable physician. }\end{array}$ & 25 \\
\hline
\end{tabular}

\section{Mentoring for first year medical students: humanising medical education}

\section{ARATI BHATIA ${ }^{1}$, NAVJEEVAN SINGH ${ }^{2}$, UPREET DHALIWAL ${ }^{3}$}

Departments of ${ }^{1,2}$ Pathology, ${ }^{3}$ Ophthalmology, ${ }^{1,2,3}$ Medical Education Unit, University College of Medical Sciences, University of Delhi, Delhi 110095 INDIA. Author for correspondence: Upreet Dhaliwal e-mail: upreetdhaliwal@yahoo.com

\section{Abstract}

New entrants are vulnerable to the challenges of the medical course; mentoring programmes are known to offer support. This paper evaluated the experiences of students and faculty enrolled in a new mentoring programme. After needs analysis of students and faculty, a small-group mentoring programme for new medical students was initiated. Fifty-five volunteer faculty mentors were allocated two-three students each. At year-end, feedback using an open-ended questionnaire, revealed that there was no contact in one-third of the cases; the commonest reasons cited were lack of mentee initiative, time and commitment. Supportive mentors were appreciated. Over $95 \%$ of respondents believed that mentoring was a good idea; many believed the mentee benefitted; mentors also reported improved communication and affective skills; 60 (77.0\%) mentees wanted to mentor new students the following year. Thus, mentoring of first-year students by faculty was effective, when contact occurred, in making the mentee feel supported. Mentoring may be a means of honing the affective domain and humanitarian instincts of medical faculty and students. 